government." lifetime and into the era of the Donatist controversy. The unique usage of the seniores in North African Christian churches suggests a movement consisting largely of indigenous Africans who naturally retained their ancestral customs and practices. $^{70}$ Such an understanding in no way portrays ethnic conflict as a factor in the persecutions of Christians or the conflict between Christian sects. ${ }^{71}$ Ethnicity is a factor, however, in forming identity, and the identity of the African early Christians, while radically transformed by their new faith, retained a selfunderstanding of their heritage, their uniqueness and their non-Romanness, in other words, their African identities.

\title{
5.4 Tertullian and Ethnic Identity
}

The indigenous Africans under Rome belonged to an ethnic category distinct from the Roman colonizers. The colonization of North Africa began a phenomenon of conflict between these two categories of peoples resulting in, among other responses, a solidified understanding of the non-Roman-ness of some of the indigenous population. As the Christian communities in North Africa incorporated a growing majority of indigenous Africans into its membership, ethnic factors began to influence the practices and self-identities of said congregations. Tertullian's constructions of ethnic boundaries such as customs and appearance will now be discussed in order to explore his distinctions between certain people groups. ${ }^{72}$ The following section assumes the tension in his

69 Ibid, 223.

70 For later African Christianity as largely indigenous, see Raven, Rome, 167; Markus, "Christianity," 21-36; Shaw, "African Christianity," who replaces "Donatist" with "African"; and Tilley, The Bible, 18, for the "remnants of Punic culture." A.H.M. Jones, "Were Ancient Heresies National or Social Movements in Disguise?" JTS 10 (1959): 280-98, argues that heresies were not nationalistic, but "regional." Jones' definition of "national," however, is rarely (if ever) proposed; instead, scholars such as Raven are cautious about labeling any form of Christianity as "nationalistic" or coterminous with an ethnic identity, but continue to recognize the trends of some sects in attracting certain people groups. Moreover, as Buell, "Race and Universalism," 468, maintains, "Paying attention to ethnic reasoning helps us reconstruct the diversity among early Christian thinking and practices without recourse to problematic frameworks like orthodoxy, heterodoxy, and heresy." For responses to Jones, see Frend, "Heresy," 39; Markus, "Christianity and Dissent," 25-6; and Ramsay MacMullen, "Tertullian and "National God," JTS n.s. 26 (1975): 405-10.

71 See, however, Christopher D. Stanley, “Neither Jew nor Greek': Ethnic Conflict in GraecoRoman Society," Journal for the Study of the New Testament 64 (D 1996): 101-124, for this phenomenon throughout the Roman Empire and its import for Paul's writings.

72 The lack of data regarding Tertullian's native language requires the subject to be omitted from the present discussion. See, however, H. Hoppe (1932), cited by Altaner, Patrology, (1960), 166, who states, "Tertullian formed 509 new nouns, 284 new adjectives, 28 new adverbs and 161 new verbs..." Although the notion of an "African dialect" of Latin has found little support in contemporary scholarship - see generally, Hilton, "Introduction by John Hilton to Florida in 
construction of ethnic boundary markers which should be seen in light of his Christian identity (see below).

\subsubsection{Ethnicity and Tertullian's Ethnic Boundaries}

Did Tertullian explicitly discuss his ethnic identity or that of the Christian community to which he belonged? ${ }^{73}$ Leyerle says that Tertullian understood Christians, like Jews with circumcision, to have a "shared ethnic identity" and this new identity angered the Graeco-Romans. ${ }^{74}$ While Leyerle focuses on Tertullian's usage of ethnic categories for the new Christian community, the following discussion will present evidence of Tertullian's usage of ethnic categories more generally, showing his awareness of such distinctions and their importance. Another discussion of Tertullian's ethnicity is found in Braun's article, "Aux Origines de la Chrétienté d'Afrique: un Homme de Combat, Tertullien." Because of Tertullian's anti-Roman statements in De pallio and elsewhere, Braun argues, "All of this could even make one think more precisely of a Punic origin [for Tertullian]. It is difficult to decide, however, because the entire heritage of Carthage and its glory had become common to the many African Berbers on whom the large city had for many centuries already made a significant impact."75 Braun proceeds to declare that Tertullian was Punic based on certain parallels between the Punic religion and the unique traits of North African Christianity. ${ }^{76}$ Braun's approach contributes little more than points of comparison between North African Christianity and the Libyo-Punic ethnic groups as seen by one scholar. His study does illustrate, however, the need to further investigate Tertullian's own usage and discussion of ethnic indicators in order to better understand the conflict found in much of the North African's writings.

As shown above, Tertullian claimed Africa as his patria, and since a homeland has been delineated as a common concept in forming ethnic categories,

Apuleius," 133-4; and for Tertullian's Latin, René Braun, "Tertullien et le renouvellement du latin," in Pères de l'Église au XXe siècle, (Paris: Editions du Cerf 1997), 265-274. Tertullian's adaptation of Latin raises questions as to whether or not it was his native language. Regarding Greek, he seems to exclude it as his sermo: $A d u$. Marc. 3.22.6; and see $A d u$. Prax. 3.2, where Tertullian seems to indicate that both Greek and Latin were acquired.

73 Patristic scholars can allude to Tertullian's ethnicity: e.g. Altener, Patrology, 167, "He combined Punic fervour with Roman practical sense."

74 "Blood is Seed," 42.

75 "Aux Origines," 194: Tout cela pourrait même faire penser plus précisément à une origine punique; mais il est difficile de se prononcer, car dpuis plusieurs siècles déjà tout le patrimoine des gloires carthaginoises était devenu commun aux Africains berberes sur qui s'était marquée profondément l'empreinte de la grande cité.

76 Also, Wright, "Tertullian," 1029, surmises, "Although its earliest roots in Carthaginian society remain hotly contested more than one aspect of Tertullianic Christianity may well reflect the residual influence of the grim child-sacrificing Punic religion of pre-Roman Carthage." 
Tertullian's own understanding of his ethnicity comes into question. Another important indicator of ethnic identity for recent anthropological studies is that of dress. ${ }^{77}$ Dress must be understood as more than simply garments, but rather as any modifications of appearance including hair, makeup, accessories, scents and tattooing. ${ }^{78}$ More pertinent to this discussion is the function of dress as a boundary marker between ethnic groups.

Dress, according to Eicher, is a "coded sensory system" which links ethnicity and ethnic identity on the part of the individual wearing the dress and the outsider viewing the individual. ${ }^{79}$ A community can utilize this symbolic nature of dress to construct its own identity with traditional attire and accessories. "In other words," Eicher argues, "...Ethnicity embraces ideas of group cohesion, of insiders versus outsiders, with boundaries that separate outsiders and insiders and symbols that identify members of a group as being distinct from other groups." 80 While some recent studies view ethnic groups' use of dress as a reaction to modernism, many scholars view dress in terms of Postcolonial response. ${ }^{81}$

One Postcolonial perspective on dress and ethnicity is Fadwa El Guindi's explication of the veil in his work, Veil: Modesty, Privacy and Resistance. Following a diachronic approach, Guindi begins in the ancient world, explaining the various uses of the veil and its developing importance as "a symbol ideologically fundamental to the Christian, and particularly the Catholic, vision of womanhood and piety, and a vehicle for resistance in Islamic societies."

77 See M.E. Roach and Joanne. B. Eicher, Dress, Adornment and the Social Order, (New York: John Wiley, 1965); Roach and Eicher, The Visible Self: Perspectives on Dress, (Englewood Cliffs, N.J.: Prentice Hall, 1973); Roach and Eicher, "The Language of Personal Adornment," in The Fabric of Culture: The Anthropology of Clothing and Adornment, eds. Justine M. Cordwell and Ronald A. Schwar, (The Hague: Mouton Publishers, 1979), 7-22; Eicher, "Introduction: Dress as Expression of Ethnic Identity," in Dress and Ethnicity: Change Across Space and Time, ed. Eicher, (Oxford: Berg, 1995), 1-5.

78 Roach-Higgins and Eicher, "Dress and Identity," 1-8, cited in Fadwa El Guindi, Veil: Modesty, Privacy and Resistance, (Oxford: Berg, 1999), 55.

79 "Introduction: Dress as Expression of Ethnic Identity," 1.

80 Eicher and Barbara Sumberg, "World Fashion, Ethnic and National Dress," in Dress and Ethnicity, ed. Eicher, 301.

81 For the modernism explanation, see Malcolm Chapman, "Freezing the Frame: Dress and Ethnicity in Brittany and Gaelic Scotland," in Dress and Ethnicity, ed. Eicher, 7-28, and Ann Bridgewood, "Dancing the Jar: Girls' Dress at Turkish Cypriot Weddings," in Dress and Ethnicity, ed. Eicher, 29-49. In contrast to the modemity explanation, however, see Elisha P. Renne, "Becoming a Bunu Bride: Bunu Ethnic Identity and Traditional Marriage Dress," in Dress and Ethnicity, ed. Eicher, 117-37; and Eicher and Tonye V. Erekosima, "Why do They Call it Kalabari? Cultural Authentication and the Demarcation of Ethnic Identity," in Dress and Ethnicity, ed. Eicher, 139-164.

82 Veil, xii. It should be noted that a "veil" refers to any form of covering the head, face and/or neck and shoulders in anthropological terms. This coincides with the usage found in Tertullian; see De uirg. uel. Additionally, Charles-Picard and Charles Picard, Daily Life, 136, claim that head gear was common garb in Carthage. Also note the gender identity concurrently invoked in such a discussion. 
ancient uses of dress informed Guindi's research, it is argued here that the converse is also true in the hermeneutical spiral of interpretation, and Guindi's understanding can in turn inform a reading of Tertullian's works. As Ann Bridgewood has argued, "Dress is never value-free; there is no style which does not carry some connotation of, for example, imperialism, oppression or liberation. ${ }^{, 83}$ Other approaches have likewise found the category of ethnic dress valuable for the discussion of late antiquity.

In the ancient world dress, including hair and accessories, served to delineate certain people groups from others. Pohl's study of ethnicity in the Roman empire finds more ancient sources relying on dress as ethnic indicators than any other signifier ${ }^{84}$ He notes specifically hair as a sign used by Roman writers to separate themselves from all "barbarians." 85 Several ancient authors comment on the trend for Roman women to bleach their hair blond or dye it red to imitate the northern Germanic and Gaulic peoples. ${ }^{86}$ Tertullian, when rebuking women who have dyed their hair, declares, "They are ashamed even of their own nation, (ashamed) that their procreation did not assign them to Germany and to Gaul" (Pudet eas etiam nationis suae quod non Germaniae atque Galliae sint procreatae, De cult. fem. 2.6.1). ${ }^{87}$ Tertullian understood appearance as a boundary which separated

83 "Dancing the Jar," 48.

84 "Telling the Difference," see his section on "Hairstyles and Body Signs," 51-61. For a North African Christian example, see Tilley, "The Passion," 849, who comments on the Perpetua and her fellow martyrs" command to wear the garb of Roman cults, deemimg "Clothing as an extension of the body and thus as an expression of identity...."

85 Pohl, "Telling the Difference," 54; ref. Seneca, Epistula 124.22, "Why dress your hair with such unending attention? Though you let it down in Parthian fashion, or tie it up in the Germans style, or, as the Scythians do, let it flow wild" [Quid capillum ingenti diligentia comis? Cum illum uel effunderis more Parthorum vel Germanorum modo uinxeris uel, ut Scythiae solent, sparseris].

86 See Thompson, Blacks, I3lff. for discussion; one example suffices: Propertius 2.18d, "Do you still in your madness imitate the painted Britons and play the wanton with foreign dyes upon your cheeks? All beauty is best as nature made it: Belgian rouge is shameful on a Roman face. If some woman has stained her forehead with azure dye, is azure beauty on that account to be desired? In hell below may many an ill befall that girl who stupidly dyes her hair with a false colour!" [Nunc etiam infectos demens imitare Britannos, ludis et externo tincta nitore aput? Ut natura dedit, sic omnis recta figuasti turpis Romano Belgicus ore color. An si caeruleo quaedam sua tempora fuco tinxerit, idcirco caerula forma bonast? Illi sub terris fiant mala multa puellae, quae mentita suas uertit inepta comas!]

87 Thompson, Blacks, 132, comments on this passage, attributing Tertullian's stance to the audience's "inferiority complex about their ethnic identity." Although Tertullian himself makes little use of physical characteristics as an ethnic boundary marker (in fact, in De an. 25.6-8 he seems to refute the three-tiered model of climate-derived somatic types discussed in above, section 5.2), it is interesting to compare the way scholars have portrayed him: e.g. J. D. Woodbridge, ed., Great Leaders of the Christian Church (Chicago: Moody, 1988), 49, depicts him wearing a turban; whereas, more recently, Dunn, Tertullian, has on his cover, the mosaic of the personified Africa from El Djem Museum (this image is discussed above and in BlanchardLemée, Ennaïfer, Slim and Slim, Mosaics of Roman Africa, 18-34). Additionally, Dunn, Tertullian, 6, ventures to "hazard a guess" that Tertullian was bearded; ref. De spect. 23.3. 
one people group from another, and, when he addresses the hairstyles of Christian women, he emphasizes the importance of distinction not only between Christians and non-Christians, but between specific ethnic groups as well. ${ }^{88}$

In his treatise, De uirginibus uelandis, Tertullian also comments on many aspects of women's fashion, including how women "dye their hair; and fasten their hair with more wanton pin, ...they consult the looking-glass to aid their beauty, and thin down their over-exacting face with washing, perhaps withal vamp it up with cosmetics, toss their mantle about them with an air, fit tightly the multiform shoe, carry down more ample appliances to the baths." 89 Tertullian speaks of the women's dress within a polemic of whether or not virgins should be veiled in the church service. He argues in favor of the practice, and in doing so laments over the tragic happenings to his religious community of North Africa:

O sacrilegious hands, which have had the hardihood to drag off a dress dedicated to God! What worse could any persecutor have done, if he had known that this (garb) had been chosen by a virgin? You have denuded a maiden in regard of her head, and forthwith she wholly ceases to be a virgin to herself; she has undergone a change! ${ }^{90}$

While one reading of this passage could understand Tertullian's cry figuratively, from a Postcolonial interpretation a more serious concern is also possible in these words.

In his section "The Resistance of the Veil" in which he analyzes Frantz Fanon's understanding of the French "unveiling" of Algeria, Guindi says that the French colonial attempts "to modernize" Algeria were actually anti-nationalistic tactics, and the "Algerians saw among settler Europeans a hidden desire to rape, literally and figuratively" by unveiling the women. ${ }^{91}$ Tertullian understands the

88 Given the antipathy towards Romans in De cult. fem., Tertullian likely attacks wealthy women who, like Romans, mimic the hair of the Germans and Gauls. For a discussion of women's hairstyles in Rome at this time, see Mary G. Houston, Ancient Greek, Roman and Byzantine Costume and Decoration, 2nd ed., (London: Adam \& Charles Black, 1947), 116, where she illustrates several examples of hairstyles which "give an idea of the enormous importance of coiffure in the otherwise very simple and almost unchangeable costume of the Roman lady during the first two centuries of the Christian Era."

89 De uirg. uel. 12.3-4: uertunt capillum et acu lasciuiore comam sibi inferunt...consilium formae a speculo petunt et faciem morosiorem lauacro macerant, forsitan et aliquo eam medicamine interpolent, pallium extrinsecus iactant, calceum stipant multiformem, plus instrumenti ad balneas deferunt.

90 De uirg. uel. 3.8: O sacrilegae manus, quae dicatum deo habitum detrahere potuerunt! Quid peius aliquis persecutor fecisset, si hoc a uirgine electum agnouisset? Denudasti puellam a capite et nota iam sibi uirgo non est, alia est facta.

91 Veil, 170ff., ref. A Dying Colonialism, trans. Haakon Chevalier, (New York: Grove Press, 1967). cf. Tertullian's statement (De pud. 1.13-14), where he reminds fellow-Christians, "Heathendom itself bears such emphatic witness, that it strives to punish that discipline in the persons of our females rather by defilements of the flesh than tortures; wishing to wrest from them that which they hold dearer than life!" [ipsum quoque saeculum usque adeo testatur, ut, si quando, eam in feminis nostris inquinamentis potius carnis quam tormentis punire contendat id 
"world" in opposition to his Christian community, and one means of protecting the boundary between themselves and foreigners involves more than a Christian/non-Christian distinction, but it requires an establishment of an ethnic boundary by means of dress.

In seeking to understand Tertullian's passages, Pohl's warning is pertinent regarding the complexity involved in the ancient society: often dress was more a sign of social status than ethnic identity. ${ }^{92}$ To this complexity could be added religion, clan, gender and many other factors. Pohl does, however, proceed to give several examples where ancient accounts of dress signify ethnic identities, indicating the need for careful examination of the textual witness when determining its usage. On certain occasions, Tertullian's concern with outsider influence on his (predominantly African) Christian community recognizes in dress a means of stating ethnic identity; this is most evident in his work $D e$ pallio. ${ }^{93}$

uolens eripere quod uitae anteponunt]; and Apol. 50.12 (Souter): "For quite recently by condemning a Christian woman to the lust of man rather than to a lion, you confessed that the stain upon chastity is reckoned more heinous among us than any punishment and any death" [Nam et proxime ad lenonem damnando Christianam potius quam ad leonem, confessi estis labem pudicitiae apud nos atrociorem omni poena et omni morte reputari]. cf. Amobius, 1.64; 2.1; and 2.45.2. See also the accusation against Severus' army by Herodian 3.9, "Falling upon the barbarians unawares, the Romans slaughtered any they met and plundered the whole area of the city, making prisoners of all the women and children" [

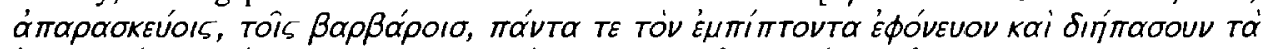

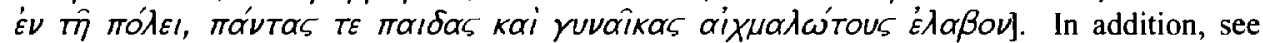
S.R. Joshel, "The Body Female and the Body Politic: Livy's Lucretia and Verginia - Source: Livy, 'On the Founding of Rome' 1.57.6-59.6," Sexuality and Gender (2002), 177, who argues that Livy's account of Lucretia's rape by the last Roman prince is an attack on "what Roman 'soldier males' do to the conquered"; Cherry, "The Marriage of Equestrian Officers in the PostSeveran Army," Historia 46 (1 1997), 113, who argues that the law (ref. Digesta 23.2.63) prohibiting soldiers from marrying provincials "was probably meant to protect provincial women from being forced into marriage"; J. Evans-Grubbs, "Abduction Marriage in Antiquity: A Law of Constantine (CTh IX.24.1) and Its Social Context," JRS 79 (1989): 59-83, who argues that Constantine's edict against marriages by abduction, formally recognized a practice that had taken place for centuries; and Lefkowitz, Heroines, 57, who speculates that Perpetua was raped by her father. For Tertullian's use of Lucretia as a positive example to female Christians awaiting torture and execution, see Ad mart. 4; and below, section 6.4.1.

92 Pohl, "Telling the Difference," 40-51.

93 For another instance where Tertullian explains how ethnic groups such as the Garamantes, Germans, Athenians and Britons can be distinguished by dress in De uirg. uel., see 10.1-2; note the correlation between Tertullian's examples and the directional perspective of both Rome and Carthage (respectively, South, North, West and East.) This perspective especially seems to point to a Roman centre, given the fact that each group represents some form of resistance to the Romans. For an example of a surviving Mosaic where Rome is depicted as central, personified, holding an orb in her hand and surrounded by personified provinces: BlanchardLemée, Ennaïfer, Slim and Slim, Mosaics of Roman Africa, 18-34. 


\subsubsection{Ethnicity in De pallio}

Tertullian's treatise, De pallio, addresses the criticism made by some against Tertullian's setting aside the toga in favor of wearing a pallium - a cloak. ${ }^{94}$ Tertullian describes the characteristics of this garb himself in his treatise after introducing his work by saying,

Men of Carthage, ever princes of Africa, ennobled by ancient memories, blest with modern felicities, I rejoice that times are so prosperous with you that you have leisure to spend and pleasure to find in criticising dress. These are the "piping times of peace" and plenty. Blessings rain from the empire and from the sky. ${ }^{95}$

In these opening lines, Tertullian sets the tone for the treatise as one of bitter sarcasm, reacting to both those "criticising dress" and those who receive the blessings "from the empire." 96

Commenting on this tone, Groh asserts that Tertullian's understanding of the Christian life requires a correlation between inner virtue and outer reality: "This is why Tertullian gives so much attention to disciplinary matters, even matters of dress, in his treatises."97 Groh continues by connecting Tertullian's Christianity with his subversive tendencies, stating,

The pallium employed in this way represents a divine dress donned to express values opposed to those of societal man in his craving for public dignity and glory, symbolized by the toga. Tertullian's pallium, like the clothes of the contemporary counter culture, was the announcement of a socio-political revolution in values based on an understanding of life at fundamental odds with the mainstream of society. ${ }^{98}$

$\overline{94}$ For commentary and discussion of De pall. see Hunink, Tertullian, who concludes that this is a speech delivered in Carthage (16).

95 De pall. 1.1: Principes semper Africae, uiri Carthaginenses, uetustate nobiles, nouitate felices, gaudeo uos tam prosperos temporum, cum ita uacat ac iuuat habitus denotare: pacis haec et annonae et otia: ab imperio et a caelo bene est. Note that after uiri Bulhart inserts Affricae on the bases of one of the older manuscripts.

96 Hunink, Tertullian, 68, "The text shows a remarkable contrast between the local African culture (of Carthage and other towns), and the Roman culture that has become dominant in the whole world. ...the contrast with Rome is further sharpened by rather sinister references to its history...." Hunink adds that Tertullian is not speaking in terms of "political resistiance or nationalistic revolt." However, on the problematic "resistiance"/"Romanization" dichotomy, see above, section 1.4 .

97 Groh, "Tertullian's Polemic," 14.

98 Ibid; cf. his note 57 on sources for the pallium as a rejection of pagan Rome; another review is in Fredouille, Tertullien, 446-7; Freduille, however, rejects these scholars' findings (448): “...un tel changement vestimentaire était-il susceptible de provoquer un «scandale $>$ quelconque à Carthage, au temps des Sévèrus? A priori, non." For recent scholarship that suggests otherwise, see above, section 1.4 . 
If Tertullian suddenly dons the pallium refusing to wear the Roman toga, then Pohl's claim that "innovation in dress often expresses more fundamental changes in society, and usually goes along with actual or intended social advancement of new groups," becomes pertinent. 99 Ancient historians disagree in their understanding of the pallium: historians of Rome can claim Tertullian refers to Greek attire while historians of Carthage can argue for a traditional African referent. ${ }^{100}$ The following analysis of De pallio agrees with the latter, understanding Tertullian's use of dress as a boundary marker of ethnic identity.

There is an ambiguity in Tertullian's De pallio as to whether or not Tertullian refers to a philosopher's cloak or a traditional African outfit. ${ }^{101}$ Several passages suggest the former in Tertullian's thought, such as when he admits, "this Mantle, albeit it is more Greek" (hoc pallium, etsi Graecum magis, 3.7). "102 He later defends the cloak, countering that "you are nevertheless Greek to a degree" (admodum Graeci, 4.1), and proceeds to explain, "A philosopher, in fact, is heard so long as he is seen. My very sight puts vices to the blush" (sic denique auditur philosophus, dum uidetur: de occursu meo uitia suffundo, 6.1) ${ }^{103}$ Clearly, these passages indicate that the Greek form of a philosopher's cloak is represented in Tertullian's treatise. ${ }^{104}$ However, would Tertullian condone wearing a

99 "Telling the Difference," 49.

100 e.g. Houston, Ancient Greek, 96-99; and Gilbert and Colette Charles-Picard, Daily Life in Carthage at the Time of Hannibal, trans. A.E. Foster, (London: Ruskin House, 1961), 135, respectively. Barnes, Tertullian, 85,210 , can assume both without further elaboration. Likewise, Dunn, Tertullian, 6, 33, 41, says the pallium belonged to "the custom of the local population"; deemed it "the Greek/Punic pallium" (ultimately concluding its symbolism to be bound to philosophy), and described it as the "more native dress." Also, Hunink, Tertullian, 9, 67 , can claim the pallium is a philosopher's cloak and later claim that it is "associated with local [African] history and religion... contrasted with Roman culture." In the present discussion, suggesting the pallium an African garb is not meant to "essentialize" the physical referent. Rather, it is argued here, that Tertullian could have construed the pallium to suit his needs.

101 Price, "Latin Christian Apologetics," 110-1, allows for both. Tertullian seems to take his cue from Justin, Dialogus cum Tryphone Iudaeo 1-2. One should also note, however, that Justin neither confirms nor denies Trypho's assumption that his cloak is a philosopher's. Rather, Justin, Dialogus cum Tryphone Iudaeo 8, uses the opportunity to dileneate truth from philosophical conjecture, finding the prophets' and apostles' "philosophy alone to be safe and

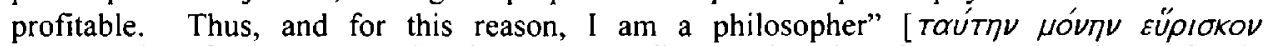

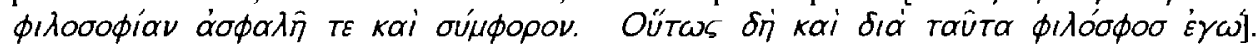
Moreover, Justin applies this device in a dialogue with a Jew who is learning philosophy, not in his writings to Romans or Greeks ( $1-2$ Apologia). The following section suggests that Tertullian accommodated Justin's actions for his own purposes.

102 In favor of the philosopher's cloak as a referent, Sider, Ancient Rhetoric, 120; Bediako, Theology and Identity, 107, relying on Fredouille, Tertullien, 448; and Wright, "Tertullian," 1039.

103 The text of 4.1 is Oehler's in agreement with most early editions; Bulhart rendered, modis ad Graios estis over still other variants, including, modis ad gratos and admodum gratios. See textual notes in A. Gerlo, CCSL 2.

104 Houston, Ancient Greek, 99, describes the pallium as "identical to the Greek himation," which is in fact simply a cloth "of great size so that it covered the figure to the feet. ...This cloak is simply thrown over the shoulders and either hangs loose or is held by the hands in front" (68). 
Philosopher's cloak, when philosophers are excluded from persecution (Apol. 46; Ad. nat. 1.4) and evading persecution is a $\sin ($ De iei. 12; De fug.)? While many other such objections could be made against exclusively associating Tertullian's pallium with the Greek philosopher's cloak, the most illuminating data comes from other arguments in De pallio.

Tertullian's use of dress involves a complex rhetorical aim, allowing ambiguity in certain passages for the sake of persuasion. Preceding any philosophical descriptions of the pallium in Tertullian's treatise are several lines that indicate an African origin and form of the garb as prominent in the author's argument. Tertullian reminds the audience, "Still, you too of old time wore your garments--your tunics--of another shape" (Tamen et uobis habitus aliter olim, tunicae fuere, 1.1), and he then contrasts the toga with the "mantle... which used to be worn by all ranks and conditions among you, you not only are unmindful of, but even deride" (et si quid praeterea condicio uel dignitas uel temporalitas uestit; pallium tamen generaliter, uestrum immemores, etiam denotatis, 1.3). ${ }^{105}$ The apologist continues his defense by reminding the Carthaginian audience of how the battering ram was invented by Carthage - and he adds that it was used by Rome to destroy Carthage - but has been forgotten by the Carthaginians; likewise, the pallium, which was the traditional and ancient dress, is now unrecognized (1.3). ${ }^{106}$ Given the duplicitous usage in Tertullian, how should one interpret his construction of the pallium?

Other examples exist in the treatise where Tertullian speaks of the pallium with still differing referents, as neither African nor Greek. Referring to the public priests and religious officials, he observes that they wear "the Mantle, above all the garments in which you array your gods and goddesses, an august robe; and, above all the caps and tufts of your Salii and Flamines, [it is] a sacerdotal attire" (pallium super omnes exuuias et peplos augusta uestis superque omnes apices et titulos sacerdos suggestus, 4.10). ${ }^{107}$ In other words, the robe Tertullian dons is similar enough in appearance with both the sacerdotal garments of many cults and the philosopher's cloak worn by many throughout the Roman empire for the apologist to claim them as one and the same pallium for the sake of argument. Such an understanding explains Tertullian's statement about the pragmatic benefits of his outfit: "But, than the Mantle nothing is more expedite, even if it be double, like that of Crates" (At enim pallio nihil expeditius, etiam si duplex, quod

105 On 1.1 Hunink, Tertullian, 71, comments, "The contrast between 'Carthage' and 'Rome' still remains implicit here...." And on 1.3, Hunink (84) states, "The speaker drives home his point by expressly repeating the Carthaginian origin of the old pallium...."

106 ref. Virgil, Aeneid 1.14, 3.415. Hunink, Tertullian, 87, stipulates, "One may argue, however, that the quotation of Vergil is more than just decorative, as it adds to the speaker's obvious intention of appealing to nationalistic feelings of his audience."

107 Bulhart replaces titulos with tutulos on the witness of the 1622 edition of Claudius Salmasius who reviewed manuscripts no longer extant. 
Cratetis, 5.3). ${ }^{108}$ Tertullian compares the pallium to the Cynic's attire, insinuating that the former is like the latter but not actually equal to it.

The pallium worn by Tertullian coincides with the traditional manner of dress referred to in the opening paragraph of the treatise. The differing explanations and comparisons, such as philosophers' and priests' wardrobes, derive from Tertullian's deliberate shift in argument found in the second paragraph. ${ }^{109}$ After alluding to Rome's destruction of Carthage, and quoting its celebration by Virgil (ref. Aen. 1.3), Tertullian agrees to abate the intensity of his rhetoric: "Draw we now our material from some other source, lest Punichood either blush or else grieve in the midst of Romans" (Sit nunc aliunde res, ne Poenicum inter Romanos aut erubescat aut doleat, 2.1). ${ }^{110}$ In so doing, Tertullian proceeds to illustrate his defense with non-African examples of attire, so as to make his argument more palatable to his audience. ${ }^{111}$

The audience, as addressed in the opening to the principes semper Africae, uiri Carthaginienses, consists of the new elite of Africa. ${ }^{1 / 2}$ They themselves represent and mimic the many who have followed Rome, especially "in the way of dress ...precocious in Romanizing" (de habitu... Romanum praecoca, 1.2). ${ }^{113}$ Moreover, Tertullian's new elite audience become embarrassed by the type of individuals who also wear the toga, such as "branded slaves" (dediticios), the "notoriously infamous" (subuerbustos), "clowns" (rupices), "buffoons" (scurras), "rustics" (paganos), the "corpse-bearer" (uespillo), the "pimp" (leno) and the "gladiator-trainer" (lanista, 4.8).

Before discussing the practicality of the pallium, Tertullian subtly retorts, "Did Anacharsis change otherwise, when to the royalty of Scythia he preferred philosophy? Grant that there be no (miraculous) signs in proof of your transformation for the better: there is somewhat which this your garb can do" ( $A n$ aliter mutauit Anacharsis, cum regno Scythiae philosophiam praeuertit? Nulla in

108 For ancient sources on Crates' pallium, see Hunink, Tertullian, 254-5.

109 See Hunink, Tertullian, 91, on this structural shift in Tertullian's argument.

110 This and other passages, lead L.E. Elliot-Binns, The Beginnings of Western Christendom, (London: Lutterworth Press, 1948), 151, to conclude, "In [Tertullian] the characteristics of the African Church and of the Phoenician people, of whom he was so proud, are combined."

111 Hunink, Tertullian, 90, comments, "By broadening his minor theme to a major world wide phenomenon, the speaker gains safe territory, where he can dwell for some time...." And later Hunink notes (91), "Significantly, the name of Carthage, which was mentioned no fewer than four times in the introductory chapter, does not reappear."

112 cf. Apuleius, Flor. 16.1, "chief citizens of Africa" [principes Africae uiri]; and where Apuleius represents himself as the spokesperson for the entire province of Africa: Flor. 9.36-40. Hunink, Tertullian, 19, claims a public and therefore diverse audience, but adds "the elite might be sensitive to the more hidden notes of philosophy, religion, and politics."

113 For the toga as a common symbol of Roman power, see Virgil, Aeneid 1.282, “...The Romans, lords of the world, and the nation of the toga" [Romanos, rerum dominus, gentemque togatam]. This passage is quoted by Martial in his allusion to Domitian: Epigrammaton 14.124, "He that gave the stars to his great father makes the Romans lords of the world and people of the gown" [Romanos rerum dominos gentemque togatam ille facit, magno qui dedit astra patri]. 
melius transgressi sint digna: est habitus iste, quid faciat, 5.1). ${ }^{114}$ As shown in chapters three and four, Anacharsis served as proof for many African new elites that their "barbaric" identity was surmountable. Tertullian's remark suggests an audience of new elites who would have recoiled at his distinction. Groh understands Tertullian to be subversive, stating, "To wear the pallium cut at the roots of social co-optation by proclaiming a renunciation of the pursuit of public office and social rank."115 By suggesting through attire a renunciation of such pursuits, Tertullian aims at the vulnerability of the African new elite. ${ }^{116}$

The ancestral attire serves as an ethnic boundary marker in De pallio which separates Africans from Romans, a distinction many new elites sought to overcome. Conversely, Tertullian sees the toga as the boundary marker established by Romans in Romanization; he sardonically comments, "from the shoulders of the sublimer people [the toga] should descend to embrace Carthaginians" (ut ab humeris sublimioris populi Carthaginienses complecteretur! 1.2). Exposing the posture of new elites towards Rome, Tertullian reframes the assumptions regarding Rome's beneficence towards the provinces, and his "tone is unmistakably sarcastic":

How large a portion of our orb has the present age reformed! how many cities has the triple power of our existing empire either produced, or else augmented, or else restored! While God favours so many Augusti unitedly, how many populations have been transferred to other localities! how many peoples reduced! how many orders restored to their ancient splendour! how many barbarians baffled! In truth, our orb is the admirably cultivated estate of this empire. ${ }^{117}$

The new elites, however, consider Tertullian's proposal that they should reclaim their African ethnic identiy by reappropriating the pallium unacceptable. He, therefore, turns the argument to show that many of their acculturated customs, such as athletic games, derive originally from Greece, not from Rome.

The question, then, arises, "Why, now, if the Roman fashion is (social) salvation to every one, are you nevertheless Greek to a degree, even in points not honourable? (Quid nunc, si est Romanitas omni salus, nec honestis tamen modis ad Graios estis?, 4.1). Pressing the issue of the African and Roman ethnicity boundary by juxtaposing a third Hellenistic grouping, Tertullian demands, "What

114 Oehler's text reads signa for digna.

115 Groh, "Tertullian's Polemic," 14.

116 Hunink, Tertullian, 16-7, for audience, which he concludes was a public gathering of Carthaginians for Tertullian's speech.

117 "tone...": Birley, The African Emperor, 198. However, Hunink, Tertullian, 131-2, admits the possibility of irony in this passage but still understands Tertullian to praise Rome. De pall. 2.7: quantum urbium aut produxit aut auxit aut reddidit praesentis imperii triplex uirtus! Deo tot Augustis in unum fauente quot census transcripti, quot populi repurgati, quot ordines illustrati, quot barbari exclusi! Reuera orbis cultissimum huius imperii rus est. The phrase "triple power" refers to Septimius and his two sons, Caracalla and Geta, according to Bames, Tertullian, rev. ed., 329. cf. Hunink, Tertullian, for review of other opinions. 
hast thou, Libya, and thou, Europe, to do with athletic refinements, which thou knowest not how to dress?" (Quid tibi Libya, et Europa, cum xysticis munditiis, quas uestire non nosti?, 4.1). ${ }^{\text {I8 }}$ The new elite should remember what happened to Alexander the Great, who, though having conquered Media, "was conquered by Median garb" (uictus est Medica ueste, 4.6). In rejecting the trappings of the toga, the new elite, according to Tertullian, have the ability to reclaim their heritage and their ethnic identity.

Tertullian alternates between presenting the negative aspects of the toga and the positive role of the pallium. His explication of the inconvenience of the toga seems to be coded language meaning both the Roman costume and Roman custom - if not Roman conquest:

In short, I will persistently ask your own conscience, What is your first sensation in wearing your gown? Do you feel yourself clad, or laded? wearing a garment, or carrying it? If you shall answer negatively, I will follow you home; I will see what you hasten to do immediately after crossing your threshold. ${ }^{119}$

Tertullian offers the Africans, whom he believes to be "laded" with Rome's presence, the benefits of the pallium:

These (pleas I advance) for the Mantle in the meantime, insofar as you have defamed it by name. Now, however, it challenges you on the score of its function withal. "I," it says, "owe no duty to the forum, the election-ground, or the senate-house." ...But you will decry me as indolent. Forsooth, "we are to live for our country, and empire and estate." Such used, of old, to be the sentiment. None is born for another, being destined to die for himself. ${ }^{120}$

For Tertullian, the clothes one wears signify not only class and status, but one's loyalties to certain ethnic groups. ${ }^{121}$ In resistance to the toga he offers the pallium, and yet, Tertullian's argument defies oversimplification of categories as evidenced by his conclusion.

118 Hunink, Tertullian, 183, notes that "Libya" represents Africa, while "Europe" symbolizes Rome. Correspondingly, "Asia," mentions in the previous sentence refers to Greece, the third destabilizing identity.

119 De pall. 5.2: Conscientiam denique tuam perrogabo, quid te prius in toga sentias, indutumne an onustum, habere uestem an baiulare. Si negabis, domum consequar, uidebo, quid statim a limine properes: nullitus profecto alterius indumenti expositio quam togae gratulatur. cf. Hunink, Tertullian, 250, who explains how his translation, "dressed or oppressed" retains the pun.

120 De pall. 5.4: Haec pro pallio interim, quantum nomine comitiasti; iam uero et de negotio prouocat. 'Ego' iniquit 'nihil foro, nihil campo, nihil curiae debeo... Sed ignauam infamabis, scilicet: Patriae et imperio reique uiuendum est; erat olim ista sententia: "Nemo alii nascitur moriturus sibi." "

121 On De pall. 5.4, Hunink, Tertullian, 260, acknowledges "an almost anti-Roman attitude." Hunink than adds, "It is perhaps no coincidence that these words are attributed to the pallium rather than expressed by the speaker on his own account." 
When the apologist completes his case for choosing between the dichotomy of toga and pallium, that is between Roman and African, he then transcends the distinction with a new category, that of Christian. His conclusion states, "Joy, Mantle, and exult! A better philosophy has now deigned to honour thee, ever since thou hast begun to be a Christian's vesture!" (Gaude, pallium, et exsulta! Melior iam te philosophia dignata est, ex quo Christianum uestire coepisti, 6.2). Because Tertullian has not mentioned Christianity nor made a Christian/nonChristian distinction in the work previously, "De pallio stands out as an oddity, so much so that some have even claimed that it antedates Tertullian's conversion. This, however, is unlikely." ${ }^{22}$ What is evident in this work is the complexity involved in speaking of ethnicity in the ancient world which did not always separate issues such as class and religion. If Tertullian originally wrote De pallio from a Christian perspective, he suppresses this identity until his conclusion in order to speak as an African to Africans about their need to distinguish themselves from another ethnic group, the Romans.

$\overline{122 \text { Bray, Holiness, }}$; and see discussion in Hunink, Tertullian, 10. 